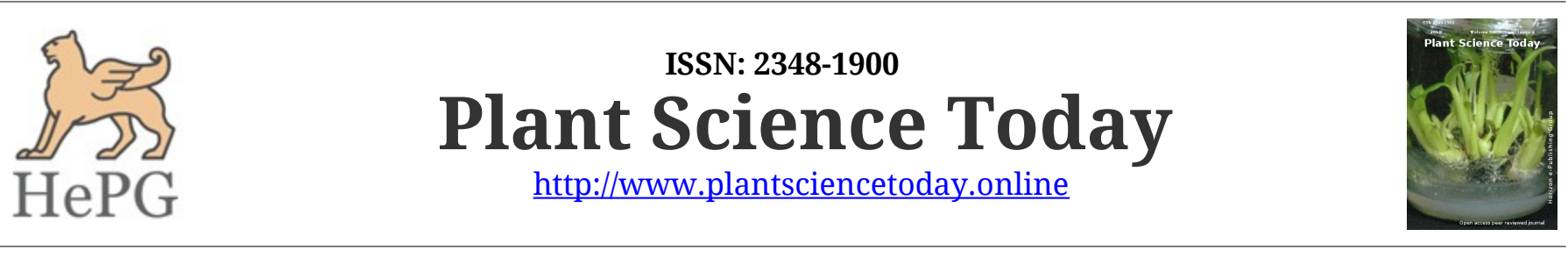

OPEN ACCESS

Research Article

\title{
Direct shoot regeneration from male immature flower buds of Musa paradisiaca Linn. cv. Poovan (AAB)
}

\author{
${ }^{1,2}$ A.R.G. Nair, ${ }^{* 1}$ P. Ravichandran and ${ }^{2}$ M. Bejoy \\ ${ }^{1}$ Department of Plant Science, Manonmaniam Sudaranar University, Tirunelveli 627 012, Tamil Nadu, India \\ ${ }^{2}$ Tissue Culture Unit, Plant Genetic Resource Division, Jawaharlal Nehru Tropical Botanic Garden and Research Institute, Palode, \\ Thiruvananthapuram 695562, Kerala, India
}

\section{Article history}

Received: 08 June 2018

Accepted: 11 September 2018

Published: 01 October 2018

\section{Editor}

Dr. Ana Isabel Carvalho, University of Trás-os-Montes and Alto Douro, Portugal

\section{Publisher}

Horizon e-Publishing Group

\begin{abstract}
A tissue culture system has been developed to multiply Musa paradisiaca cv. Poovan using male immature flower bud and to establish it in ex vitro condition. Size of explants has been found an influencing factor for culture initiation. Immature male flower bud segments of 3 $\mathrm{cm}$ size were ideal for better survival and subsequent shoot regeneration. Direct shoot regeneration was achieved from male immature flower buds on Murashige and Skoog (MS) medium supplemented with varying concentrations of plant growth regulators. Initially, actively dividing meristematic region developed at the basal region of flower buds near the bract axil, which later grew into green shoot buds in most of the PGR treatments. Single use of benzyl adenine were found beneficial than kinetin or addition of indole-3-acetic acid. Maximum production of $31.0 \pm 0.65$ shoots was achieved on MS $+3 \%$ sucrose $+6 \mathrm{mg} / \mathrm{L}$ benzyl adenine in 15 weeks. Isolated healthy shoots were rooted in half-strength MS medium with $150 \mathrm{mg} / \mathrm{L}$ activated charcoal $+30 \mathrm{~g} / \mathrm{L}$ sucrose $+1 \mathrm{mg} / \mathrm{L}$ indole-3-butyric acid within 15 days and they established successfully in greenhouse conditions with $85 \%$ survival.
\end{abstract}

\section{Keywords}

Banana; inflorescence; Immature male flower buds; Micropropagation; Musa; Poovan

\section{Citation}

Nair ARG, Ravichandran P, Bejoy M. Direct shoot regeneration from male immature flower buds of Musa paradisiaca Linn. cv. Poovan (AAB). Plant Science Today 2018;5(4):142-148. https://dx.doi.org/10.14719/pst.2018.5.4.403

Copyright: (c) Nair et al (2018). This is an open-access article distributed under the terms of the Creative Commons Attribution License, which permits unrestricted use, distribution, and reproduction in any medium, provided the original author and source are credited (https://creativecommons.org/licenses/by/4.0/).

\section{Introduction}

Bananas are traditionally known as 'Kalpatharu' in India, refers herb with all imaginable uses, because almost every part of the plant can be used in one way or another. Banana is one of the most important and remunerative cash crops in the world. Edible bananas are mostly triploid. Musa paradisiaca $\mathrm{cv}$. Poovan is belonging to the genomic group $\mathrm{AAB}$ and sub group 'Silk'. The fruits are highly palatable and sweet with inviting aroma. To meet the burgeoning demand for banana, its productivity has to be enhanced. The use of in vitro propagation techniques helped banana cultivation by providing synchronous flowering and enhanced productivity. Shoot tip has been widely employed for mass multiplication in many of the commercial cultivars $(1,2)$. Establishment of aseptic cultures from shoot tip explant in banana was a laborious 
task since explants were collected from underground stem. Inflorescence tip explants offer relatively simple system with reduced contamination rate compared to shoot tip $(3,4,5)$. The present study is aimed at exploiting the potentiality of male immature flower buds of 'Poovan' banana as an alternate for successful in vitro shoot regeneration.

\section{MATERIALS AND METHODS}

\section{Plant materials}

Inflorescences were harvested after 30-35 days of flowering from healthy and disease-free plants growing in local farms at Sasthamkotta, Kollam District, Kerala. In addition, plants raised in JNTBGRI, Palode campus (using suckers from same locality) were also used for harvesting explants. The inflorescences were taken to in vitro experiments within $24 \mathrm{hrs}$ of harvest. The bracts along with male flowers were detached until they became 6-7 cm in size. They were surface sterilized in the laminar air flow cabinet by flaming after dipping in $90 \%$ ethanol. Four or five outer protective bracts and corresponding male flowers were carefully removed with the help of sterile forceps and blade. For direct regeneration studies, intact and split (cut longitudinally into two equal halves) male immature flower bud explants of different size such as $1 \mathrm{~cm}, 3 \mathrm{~cm}$ and $5 \mathrm{~cm}$ were prepared.

\section{Culture initiation and shoot multiplication}

The explants of each category were initially cultured in separate jam bottles on MS medium (6) supplemented with $3 \%$ sucrose and $5 \mathrm{mg} / \mathrm{L}$ benzyl adenine (BA). The intact explant with $3 \mathrm{~cm}$ length was further inoculated onto a wide range of plant growth regulators (PGRs) such as $3-7 \mathrm{mg} / \mathrm{L}$ of BA, $3-6 \mathrm{mg} / \mathrm{L}$ of kinetin (KN) and $0.1,0.5,1.0 \mathrm{mg} / \mathrm{L}$ of indole-3-acetic acid (IAA) for induction and multiplication of shoot. They were subcultured periodically after 5 weeks interval onto the same media till healthy shoots appeared. The MS medium with $3 \%$ sucrose and $\mathrm{pH} 5.7$ was used as the basal medium (BM) for the study.

All media were adjusted to $\mathrm{pH} 5.7$ before adding $0.7 \%$ agar and autoclaved for $20 \mathrm{~min}$. at $121^{\circ} \mathrm{C}$. All cultures were incubated at $25 \pm 2{ }^{\circ} \mathrm{C}$, with 16 hour light period, provided by cool white fluorescent lamps. Thin hand sections of tissues developing shoots were made and stained with $1 \%$ safranin for histological examinations and microphotographs were taken by Leica DM100 digital camera attached to Leica DM 2500 trinocular microscope.

\section{Rooting and acclimatization}

Elongated shoots were used for root induction studies. Healthy shoots of about 4-5 cm size with 23 leaves were isolated individually from the bunch and transferred to rooting media containing half strength MS $+3 \%$ sucrose $+150 \mathrm{mg} / \mathrm{L}$ activated charcoal supplemented with various concentrations $(0.5-1.50 \mathrm{mg} / \mathrm{L})$ of indole-3-butyric acid (IBA). Rooted plants were carefully removed from the bottle and were washed thoroughly in tap water to remove traces of agar. Then each of the shoots was planted separately in small perforated disposable tea cups containing river sand and kept in a high humid (70-85\% RH) and semi-shade $(50 \%)$ greenhouse. These plantlets were re-potted in small polythene bags containing 3:1 potting mixture (garden soil : river sand) after 15 days and kept under same greenhouse conditions for further hardening.

\section{Statistical analysis}

All experiments were set up in a completely randomized design and represented with 10 replicates, otherwise specified. Culture responses were recorded periodically. All data were analyzed by single factor analysis of variance (ANOVA) and the means were compared using the Duncan's Multiple Range Test (DMRT) at $P=0.05$.

\section{RESULTS \\ Culture initiation and multiplication}

Male immature flower buds of 'Poovan' were investigated to develop a direct regeneration system and to establish it as a potential explant source. All cultures obtained from male immature flower buds after flame sterilization technique were free from fungal or bacterial contamination. Surface sterilization procedure employed here was simple and less laborious, hence suitable for establishing mother cultures with minimum explants. Preliminary experiments showed that size of the male immature flower bud explants affected the initial survival. Therefore, the effect of explant size on initial survival and further development were tested. All the explants were incubated onto MS media supplemented with 5 $\mathrm{mg} / \mathrm{L}$ BA. Out of the different types of explants studied, longitudinally split explants of all size showed poor survival due to browning developed at an early stage (Fig. 1). The smallest size explants $(1 \mathrm{~cm})$ inoculated onto the same medium did not survive. In the present study, $3 \mathrm{~cm}$ intact explants helped to reduce mortality significantly and gave rise to maximum survival of $80 \%$ in 'Poovan' while $5 \mathrm{~cm}$ reported only $60 \%$ survival. In the present study, the use of explants with appropriate size was found beneficial for improving initial establishment. Therefore, intact male immature flower buds (Fig. 2a) with $3 \mathrm{~cm}$ size were used as explant for further studies.

Morphogenic responses were observed in 2 weeks from $3 \mathrm{~cm}$ male immature flower buds cultured on MS basal medium supplemented with different PGR regimes (Table 1). Initial responses were visible as the explants became slightly enlarged and turned to light green in colour. In BA 


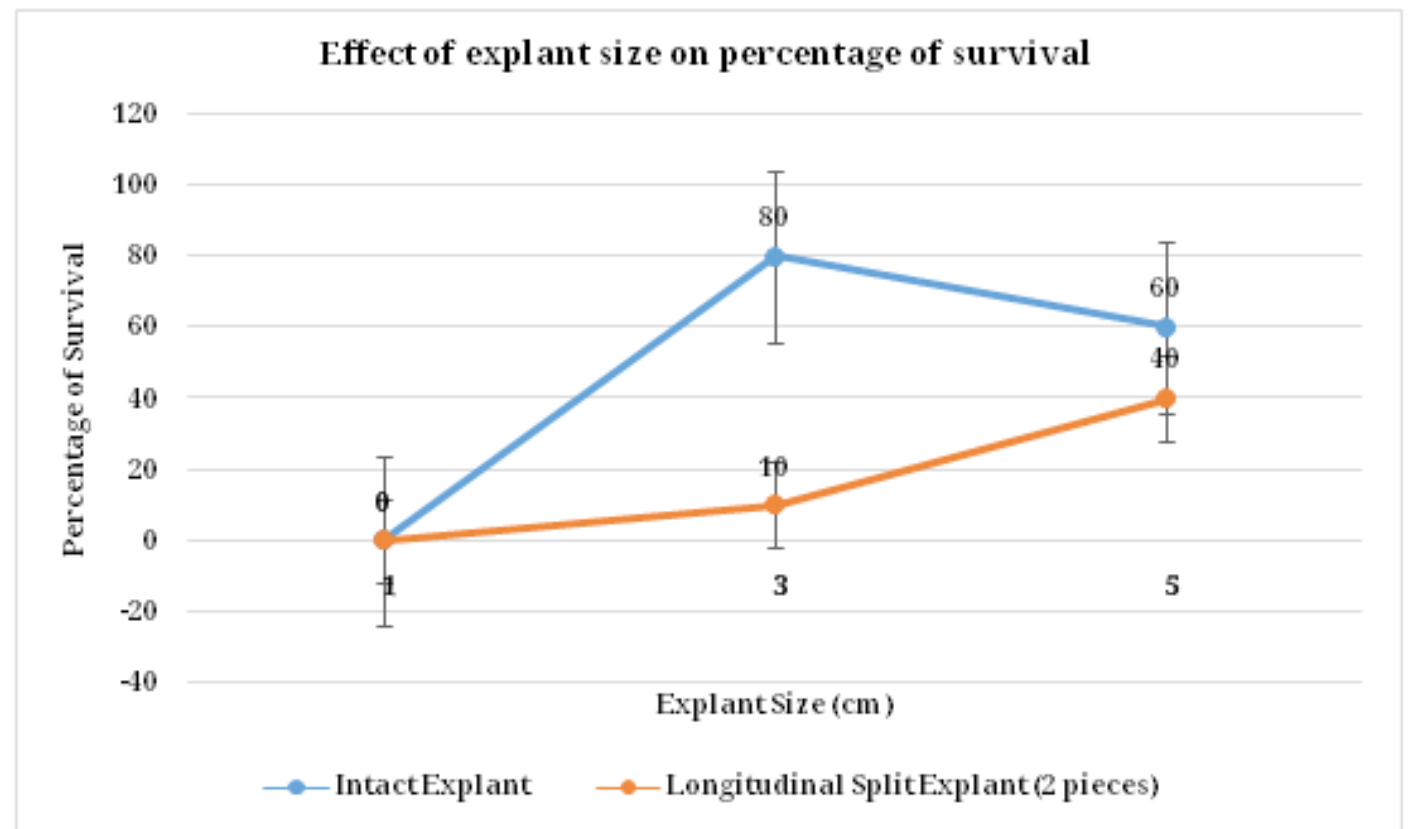

Fig. 1: Effect of explant size of male immature flower buds on percentage of survival (Basal medium: MS + BA $5 \mathrm{mg} / \mathrm{L}+30 \mathrm{~g} / \mathrm{L}$ sucrose and pH 5.7. Data were collected after 60 days of culture. ${ }^{* *}$ Average values of 5 replicates)

Table 1: Effect of growth regulators on shoot multiplication from male immature flower buds of 'Poovan' banana

\begin{tabular}{|c|c|c|c|c|c|}
\hline \multicolumn{3}{|c|}{ Treatment (mg/L)* } & \multirow{2}{*}{$\begin{array}{l}\text { Average bud/explant after } \\
10 \text { weeks }\end{array}$} & \multirow{2}{*}{$\begin{array}{l}\text { Average shoots/explant } \\
\text { after } 15 \text { weeks }\end{array}$} & \multirow{2}{*}{$\begin{array}{l}\text { Shoot length after } 15 \\
\text { weeks }(\mathrm{cm})\end{array}$} \\
\hline BA & $\mathbf{K N}$ & IAA & & & \\
\hline 3 & - & - & $4.0 \pm 0.32^{\mathrm{b}}$ & $11.3 \pm 0.53^{\mathrm{a}}$ & $6.7 \pm 0.45^{\mathrm{e}}$ \\
\hline 4 & - & - & $7.2 \pm 0.52^{c}$ & $17.0 \pm 0.75^{\mathrm{b}}$ & $5.7 \pm 0.31^{\mathrm{d}}$ \\
\hline 5 & - & - & $12.6 \pm 0.41^{\mathrm{d}}$ & $26.1 \pm 0.85^{\mathrm{cd}}$ & $4.6 \pm 0.26^{c}$ \\
\hline 6 & - & - & $16.0 \pm 0.59^{f}$ & $31.0 \pm 0.65^{f}$ & $4.3 \pm 0.32^{b c}$ \\
\hline 7 & - & - & $13.7 \pm 0.36^{\mathrm{de}}$ & $25.0 \pm 0.96^{c}$ & $3.3 \pm 0.26^{\mathrm{ab}}$ \\
\hline- & 3 & - & 0 & 0 & - \\
\hline- & 5 & - & $1.8 \pm 0.35^{\mathrm{a}}$ & $10.1 \pm 0.89^{\mathrm{a}}$ & $3.0 \pm 0.42^{\mathrm{a}}$ \\
\hline- & 6 & - & $2.6 \pm 0.26^{\mathrm{a}}$ & $9.7 \pm 0.92^{\mathrm{a}}$ & $2.8 \pm 0.29^{\mathrm{a}}$ \\
\hline 6 & - & 0.1 & $15.7 \pm 0.36^{f}$ & $29.3 \pm 0.88^{\mathrm{ef}}$ & $4.1 \pm 0.29^{\mathrm{bc}}$ \\
\hline 6 & - & 0.5 & $14.0 \pm 0.50^{\mathrm{e}}$ & $27.8 \pm 0.78^{\mathrm{de}}$ & $3.8 \pm 0.29^{\mathrm{abc}}$ \\
\hline 6 & - & 1.0 & $13.0 \pm 0.37^{\mathrm{de}}$ & $25.8 \pm 0.78^{\mathrm{cd}}$ & $3.3 \pm 0.32^{\mathrm{ab}}$ \\
\hline
\end{tabular}

*Basal medium: MS $+30 \mathrm{~g} /$ Lsucrose $\mathrm{pH} 5.7$. ${ }^{* *}$ All data were mean of 10 replicates \pm SE. Means within column having different letters are significantly different according to DMRT at 0.05 level of probability.

containing media, the bracts were split opened and the off-white male flower buds became exposed from the distal region (Fig. 2b). Almost similar responses were observed in most of BA + IAA treatments. The explants placed in KN became brown and showed visible response only after 4 weeks, but $3 \mathrm{mg} / \mathrm{L}$ did not support at all. Out of the treatments, $6 \mathrm{mg} / \mathrm{L}$ BA showed a significant difference in swelling of explants and tissue proliferation compared to other cultures. Even though bracts initially unfolded and became green in 5 and $7 \mathrm{mg} / \mathrm{L} \mathrm{BA}$, further development was slow.
After 5 weeks of incubation, they were split into two segments and subcultured onto same PGR regime after removing the bract. The tissue proliferation continued after the subculture in all treatment except in $3 \mathrm{mg} / \mathrm{L} \mathrm{KN}$. In the current study, other $\mathrm{KN}$ treatments were found less effective for shoot regeneration from male immature flower explants of 'Poovan'. In this subculture also better response has been observed in BA supplemented medium. Morphogenetic activity was more prominent at the basal area of the explant than that of tip region. Basal flower 

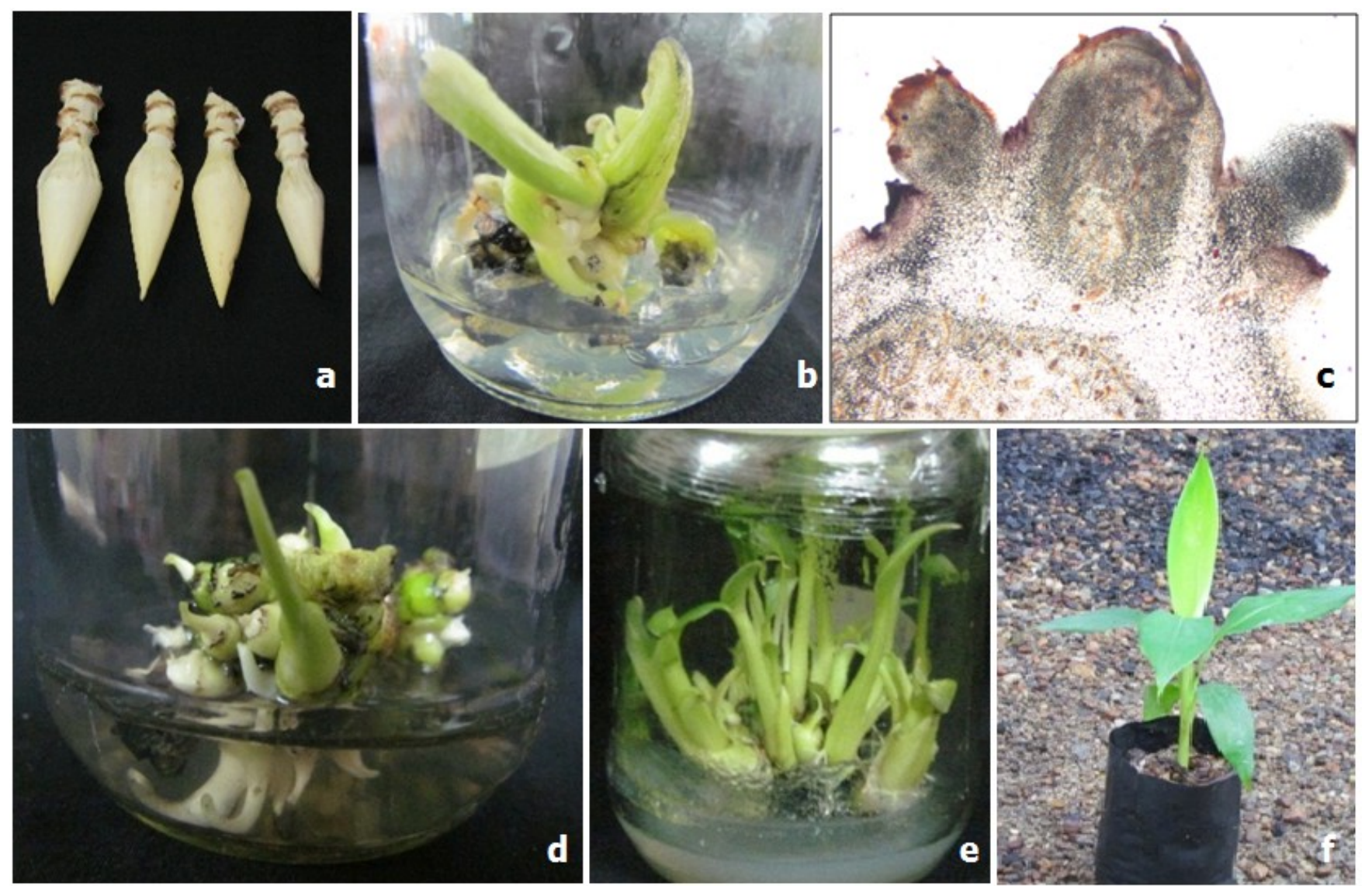

Fig. 2(a-f): In vitro propagation of Musa paradisiaca cv. Poovan using male immature flower bud explants (a) Male immature flower bud explants before sterilization; (b) Initial response of explant in BA after 4 weeks; (c) Histology of regenerating shoot buds induced from male immature flower bud segments; (d) Maximum bud production in MS + BA 6 mg/L after 10 weeks; (e) Well developed shoots obtained after 15 weeks of incubation; (f) Hardened 'Poovan' plants in polybag

buds enlarged first and gradually turned from offwhite to light green in 2 weeks after subculture. Actively dividing meristematic areas developed from the basal region of the flower buds near the bract axil were later became small protuberance like structures. Small green shoot primordia were emerged from these structures within 3 weeks after the subculture. The meristematic clusters so developed were grew into green and actively growing shoot buds in most of the PGR regimes tested in another 2 weeks (Table 1). The response was more active in BA or BA + IAA supplemented media than in $\mathrm{KN}$. At the end of the $5^{\text {th }}$ week, maximum bud development was obtained in MS medium containing BA $6 \mathrm{mg} / \mathrm{L}$, yielding $16.0 \pm 0.59$ buds (Fig. 2d). This was followed by BA $6 \mathrm{mg} / \mathrm{L}^{+}$ IAA $0.1 \mathrm{mg} / \mathrm{L}$ combination which initiated $15.7 \pm$ 0.36 buds. Other treatments were less effective in inducing shoots from male immature flower explants (Table 1). Several young buds below $1 \mathrm{~cm}$ size were also observed from the above cultures.

In order to achieve further shoot development, the shoot bunches were again subcultured ( $2^{\text {nd }}$ subculture) onto the same media and collected data after 5 weeks (Table 1). The rate of shoot production from the male flower bud segments of 'Poovan' varied with respect to the concentrations and combination of PGRs in the medium. After the $2^{\text {nd }}$ subculture, the buds grew into well developed shoots with leaves. At lower concentrations of 3 and $4 \mathrm{mg} / \mathrm{L}$ BA average shoot regeneration were $11.3 \pm 0.53$ and $17.0 \pm 0.75$ respectively in 15 weeks of culture initiation, they also well supported for shoot growth (Table 1). As the concentration of BA increased to 5 and $6 \mathrm{mg} / \mathrm{L}$, proportionate enhancements in shoot production were also observed. Maximum production of 31.0 \pm 0.65 shoots was recorded on MS $+3 \%$ sucrose +6 $\mathrm{mg} / \mathrm{L}$ BA (Fig. 2e), while $5 \mathrm{mg} / \mathrm{L}$ BA initiated $26.1 \pm$ 0.85 shoots. Reduced shooting response was also recorded in enhanced BA level of $7 \mathrm{mg} / \mathrm{L}$. Incorporation of IAA along with BA did not improve shoot developing ability of the explant, but decreased the production. Basal medium with $6 \mathrm{mg} / \mathrm{L} \mathrm{BA}+0.1 \mathrm{mg} / \mathrm{L}$ IAA yielded an average $29.3 \pm$ 0.88 shoots which were the best result under BA+IAA regime. Other combinations were less productive. As in other developmental stages, KN was less influential in shoot production in this subculture compared to other treatments. MS medium supplemented with $\mathrm{KN}$ at $5 \mathrm{mg} / \mathrm{L}$ induced only of $10.1 \pm 0.89$ shoots, which was maximum among KN treatment. Compared to single BA treatments, shoot growth and elongation responses were less in all other treatments. Shoots regenerated in lower concentrations of BA showed robust growth in 'Poovan'. The shoot elongation response was inversely proportional to the concentration of BA tested. Average shoot lengths were $6.7 \pm 0.45$ and $3.3 \pm 0.26 \mathrm{~cm}$ in media supplemented with BA 3 and $7 \mathrm{mg} / \mathrm{L}$ respectively. 
Table 2: Effect of IBA on root induction from shoots of 'Poovan'

\begin{tabular}{|c|c|c|}
\hline $\begin{array}{c}\text { Treatment }(\mathrm{mg} / \mathrm{L})^{*} \\
\text { IBA }\end{array}$ & Average No. of Roots $( \pm \mathrm{SE})^{* *}$ & $\begin{array}{l}\text { Root Length }( \pm \text { SE) })^{* *} \\
\text { (In cm) }\end{array}$ \\
\hline 0.50 & $2.12 \pm 0.12^{\mathrm{a}}$ & $1.87 \pm 0.12^{\mathrm{a}}$ \\
\hline 0.70 & $5.12 \pm 0.22^{\mathrm{b}}$ & $4.87 \pm 0.29^{b}$ \\
\hline 1.00 & $6.25 \pm 0.36^{c}$ & $5.87 \pm 0.22^{c}$ \\
\hline 1.25 & $6.00 \pm 0.18^{\mathrm{c}}$ & $5.00 \pm 0.26^{b}$ \\
\hline 1.50 & $5.00 \pm 0.37^{b}$ & $4.62 \pm 0.18^{\mathrm{b}}$ \\
\hline
\end{tabular}

*Basal medium: $1 \frac{1}{2} \mathrm{MS}+30 \mathrm{~g} / \mathrm{L}$ sucrose $+150 \mathrm{mg} / \mathrm{L}$ activated charcoal + 7g/L agar and $\mathrm{pH} 5.7$ **All data after 15 days and values are mean \pm SE, Means within column having different letters are significantly different according to DMRT at 0.05 level of probability.

Anatomical studies of regenerating tissues using hand sections revealed that numerous buds were originated from the periphery of the tissues and they seem to be epidermal or subepidermal in origin. The buds with different sizes were also noticed, showing the possibility of continuous shoot production. Vascular connections with the mother tissues were also visible. Leaf primordia from the growing tip were also seen from young buds (Fig. 2c).

\section{Rooting and acclimatization}

Healthy shoots of about $4 \mathrm{~cm}$ size with at least 2-3 leaves were isolated individually from the bunch and cultured for in vitro root development. The rooting medium comprised of half strength MS + $3 \%$ sucrose $+150 \mathrm{mg} / \mathrm{L}$ activated charcoal augmented with different concentrations of IBA (Table 2). All shoots initiated roots in the above treatments, irrespective of concentrations tested. The shoots achieved best rhizogenic activity of average $6.25 \pm 0.36$ roots with $5.87 \pm 0.22 \mathrm{~cm}$ root growth in $1.0 \mathrm{mg} / \mathrm{L} \mathrm{IBA}$ in 15 days, followed by 1.25 $\mathrm{mg} / \mathrm{L}$ IBA. Poor rooting response was observed in lower concentrations of IBA (Table 2). After the rooting phase, the plantlets were deflasked and transplanted to ex vitro condition. The plants planted in disposable tea cups containing river sand showed initial establishment in 15 days under greenhouse conditions. They were then repotted in small poly-bags containing 3:1 potting mixture (garden soil: river sand) for secondary hardening. These plants recorded $85 \%$ survival and attained $15-20 \mathrm{~cm}$ size in $6-7$ weeks (Fig. 2f). Plants raised from male immature flower buds of 'Poovan' were healthy and morphologically similar to that of clonally propagated plants.

\section{DISCUSSION}

\section{Shoot initiation and multiplication}

The present study exploited the shoot regenerating potential of male immature flower buds of Musa cv. 'Poovan'. The feasibility of utilising male immature flower bud as explants for rapid propagation of banana has been studied by many workers $(3,4,5,7,8)$. Banana micropropagation is mostly confined to the proliferation of pre-existing shoot meristem. Floral meristem that would normally produce flowers or floral parts can sometimes be induced to revert in vitro into vegetative shoot apices. Immature flower buds where the determination of the meristem is not firmly programmed and can be induced to undergo shoot regeneration. The exact stimulus leading to the reversion of floral apices into vegetative apices has not always been determined. Numerous active meristems were directly induced from the inflorescence to form multiple shoots in triploid cultivars of plantain (9). The successful culture initiation was influenced by the developmental age of the explants. Several studies in banana reported that shoot multiplication depended on the genotype of cultivars $(8,10,11)$. However, Smitha et al. (7) reported the influence of both genotypes and explant size on the rate of shoot multiplication. Whereas the present study showed that explant size influenced the rate of survival and cytokinin concentration affect multiplication. The male immature flower bud explants of 'Poovan' with optimum length $(3 \mathrm{~cm})$ exhibited better survival while smaller, bigger or split explants were found to be not ideal for culture initiation. Size of the male inflorescences has been observed as an influencing factor for culture initiation and subsequent shoot regeneration in banana. Darvari et al. (12) utilised $4 \mathrm{~cm}$ explants and achieved in vitro shoot regeneration from four triploid cultivars while Smitha et al. (7) achieved good response from 4-5 $\mathrm{cm}$ intact male inflorescence of diploid cultivars.

Explants excised from plants generally do not have enough growth substances for its growth and development hence require an exogenous supply of PGRs. Cytokinins generally stimulate tissues to undergo shoot organogenesis in vitro. The selection of cytokinins and its concentrations can have visible effect on shoot production. Shoot proliferation and elongation were affected by genotypes, cytokinins and their concentration (13, 14, 15). In the present study, BA showed maximum shoot bud induction and highest multiplication than that in KN supplemented medium. The beneficial effect of BA over other cytokinins on adventitious shoot production from inflorescence tip cultures of banana has been reported by many researchers $(16,17,8)$. Present study also illustrated that BA and its concentrations significantly influenced the rate of shoot multiplication (at $p=0.05$ ) from male immature 
flower explants of 'Poovan' and BA $6 \mathrm{~g} / \mathrm{L}$ was found ideal for maximum shoot organogenesis. In a similar study, M. acuminata cv. 'Berangan' exhibited better shoot formation from male inflorescence when treated with $7 \mathrm{mg} / \mathrm{L}$ of BA (18). Significant increase in rate of production was also noticed in 'Poovan' when the BA concentration was increased from 3 to $6 \mathrm{mg} / \mathrm{L}$ which is in accordance with the observations in the triploid cultivar 'Bwara' (19). The cytokinin requirement for shoot multiplication has also been found varying depend on the cultivars. Resmi and Nair (8) reported that in vitro responses of cultivars like 'Sannachenkadali' and 'Red Banana' were different according to BA level. In Musa cultivars, shoot multiplication is noted with a concomitant suppression of shoot elongation (20) as observed in the present study. The combined effect of BA and IAA did not improve either bud initiation or shoot growth of 'Poovan'. In contrast, synergistic effect of BA and IAA was found ideal for adventitious shoot regeneration from inflorescence apices of diploid cultivars like 'Poonkadali' and 'Rasakadali' (21). A comparative study of 12 banana cultivars revealed that the in vitro multiplication is cultivarspecific and influenced by many factors such as the culture environment (22). In the present study, maximum shoot elongation response was observed in a lower concentration of BA $(3 \mathrm{mg} / \mathrm{L})$ while bud growth was well suppressed in medium with higher concentrations of BA or in combination with IAA. This is in agreement with the findings in Musa acuminate cultivars (8). Gubbuk and Pekmezci (23) stated that moderate concentration of cytokinins increased shoot proliferation rate, but very high concentrations decreased multiplication rate and shoot elongation.

Rhizogenesis of inflorescence derived shoots of 'Poovan' was found better on $1 / 2$ MS medium supplemented with $1.0 \mathrm{mg} / \mathrm{L}$ IBA than other treatments. The present result was in conformity with the observations in 'Sabri' where the shoots showed excellent rooting in $1.0 \mathrm{mg} / \mathrm{L}$ IBA (24) and same observations were reported in the cultivar 'CV Rose' (25). While in another banana micropropagation study superior rooting response was achieved on Knudson medium containing higher concentration of $5.0 \mathrm{mg} / \mathrm{L}$ NAA (26). The survival of the plantlets in the field condition reveals the quality of the in vitro plants of inflorescence origin. The culture of male immature flower buds offers a chance to select explants from a bunch showing highly desirable agronomic and yield characteristics. The findings are also helpful in raising cultures when large number of suckers became unavailable.

\section{Author's contributions}

ARGN, conducted the experiments and carried out the statistical analysis, PR and MB designed and supervised the work.

\section{Acknowledgements}

The authors thank the Director, Jawaharlal Nehru Tropical Botanic Garden and Research Institute, Thiruvananthapuram, for providing the necessary facilities.

\section{Competing Interest}

The authors have declared that there are no competing interests.

\section{References}

1. Srivastava V, Singh AK, Singh SP. Optimization of BAP and IAA concentration on shoot induction, Proliferation and rooting in shoot-tip culture of Banana cv. Dwarf Cavendish. Ind J of Plant Physiol. 2012; 17: 179-184.

2. Nair ARG, Ravichandran P, Bejoy M. Paclobutrazol Mediated Enhanced Multiplication of Musa Paradisiaca L. cv. Poovan (AAB). Int. J. Adv. Res. 2017; 5: 2320-5407. https://doi.org/10.21474/IJAR01/4462

3. Rao SNK, Chacko EK, DoreSwamy R, Narayanasamy S. Induction of growth in explanted infloresence axis of banana. Curr. Sci. 1982; 51:666-667.

4. Cronauer SS, Krikorian AD. Reinitiation of vegetative growth from aseptically cultured terminal floral apex of bananas. American Journal of Botany. 1985; 7: 2325. https://doi.org/10.1002/j.1537-2197.1985.tb08423.x

5. Doreswamy R, Shajiram L. Micropropagation of banana from male floral apices cultured in vitro. Scientia Horticulturae. 1989; 40: 181-188. https://doi.org/10.1016/0304-4238(89)90111-8

6. Murashige T, Skoog F. A revised medium for rapid growth and bioassays with tobacco tissue cultures. Physiol. Plant. 1962; 15: 473-497. https://doi.org/10.1111/j.1399-3054.1962.tb08052.x

7. Smitha PD, Binoy KR, Nair AS. Effect of TDZ on Direct Shoot Regeneration from Whole Male Inflorescence of Four Diploid Banana Cultivars from South India, Plant Science International. 2014;1: 24-32. https://doi.org/10.12735/psi.v1n1p24

8. Resmi L, Nair AS. Plantlet production from the male inflorescence tips of Musa acuminata cultivars from South India. Plant Cell Tiss Org Cult. 2007; 88: 333338. https://doi.org/10.1007/s11240-007-9206-7

9. Krikorian AD, Irizarry $\mathrm{H}$, Cronauer SS, Rivera $\mathrm{E}$. Clonal fidelity and variation in plantain (Musa spp.) regenerated from vegetative stem and floral axis tips in vitro. Ann Bot. 1993; 71: 519-535. https://doi.org/10.1006/anbo.1993.1068

10. Israeli $\mathrm{Y}$, Lahav $\mathrm{E}$, Reuveni O. In vitro culture of bananas. In: Bananas and plantains. Chapman and Hall, London; $1995 . \quad$ p. 147-178. https://doi.org/10.1007/978-94-011-0737-2 6

11. Mendes BMJ, Flippi SB, Dementrio GB, Rodriguez AP. A statistical approach to study the dynamics of Micro propagation rate using banana (Musa spp) as example. PI. Cell Rep. 1999; 18: 967-971. https://doi.org/10.1007/s002990050692

12. Darvari FM, Sariah M, Puad MP, Maziah M. Micropropagation of some Malaysian banana and plantain (Musa sp.) cultivars using male flowers. African Journal of Biotechnology. 2010; 9: 2360 - 2366. 
13. Banerjee N, De Langhe. A tissue culture technique for rapid clonal propagation and storage under minimal growth conditions of Musa (Banana and Plantain). Plant Cell Reports. 1985; 4: 351-354. https://doi.org/10.1007/BF00269897

14. Strosse H, Van den Hauwe I, Panis B. Banana cell and Tissue culture review. In: Jain, SM \& Swennen, R (eds). Banana Improvement; Cellular, Molecular Biology and Induced Mutations. 2004.

15. Nair ARG, Ravichandran P, Bejoy $M$. In vitro shoot regeneration of Musa Paradisiaca cv. Poovan (AAB) from bract derived calli. Abstracts of the National Seminar, $17^{\text {th }}-21^{\text {st }}$ Feb 2018, National Banana Festival, Thiruvananthapuram; 2018. p. 48.

16. Cronauer SS, Krikorian AD. Rapid multiplication of bananas and plantains by in vitro shoot-tip culture. Horti Sci. 1984; 19: 234-235.

17. Jarret RL, Fisher JB, Litz RE Organ formation in Musa tissue cultures. Plant Physiol. 1985; 121:123-130. https://doi.org/10.1016/S0176-1617(85)80037-7

18. Asnita AH, Norzulaani K. Direct regeneration and RAPD assessment of male inflorescence derived plants of Musa acuminata cv. Berangan. Asia Pac. J. Mol. Biol. Biotechnol. 2006; 14: 11-17.

19. Arnaitwe G, Rubaihayo PR, Magambo MJS. Proliferation rate effects of cytokinins on banana (Musa spp.) cultivars. Sci Hort. 2000; 86: 13-21. https://doi.org/10.1016/S0304-4238(00)00124-2
20. Banerjee N, Vuylsteke D, De Langhe EAL. Meristem tip culture of Musa, histo morphological studies of shoot bud proliferation. In Withers, L. A. and Giderson, P., eds. Plant Tissue Culture and its Agricultural Applications, Butterworth, London; $1986 . \quad$ p. 139-147. https://doi.org/10.1016/B978-0-407-00921-9.50019-1

21. Mukunthakumar S, Praveen G, Seeni S. Rapid propagation of two seedless diploid $(\mathrm{AB})$ land races of Musa through in vitro culture of shoot and inflorescence apices. Tree For. Sci. Biotechnol. 2010; 4: 64-68.

22. Hirimburegama K, Gamage N. Cultivar specificity to in vitro micropropagation of Musa spp. (banana and plantain). J Hort Sci. 1997; 72: 205-211. https://doi.org/10.1080/14620316.1997.11515507

23. Gubbuk H, Pekmezci M. In vitro Propagation of Some New Banana Types (Musa spp.). Turkish Journal of Agriculture and Forestry. 2004; 28: 355-361.

24. Sultan MT, Khan MH, Hakim ML, Mamun ANK, Morshed $\mathrm{MA}$, Islam MR, Islam MR. In vitro plant regeneration from male flowers of banana. IJB.2011; 1:1-11.

25. Radhika BJ, Sreekumaran MK, Bejoy M. In vitro regeneration studies in Musa acuminata cultivar CV Rose (AA) using inflorescence apices. Abstracts of the National Seminar, $17^{\text {th }}-21^{\text {st }}$ Feb 2018, National Banana Festival, Thiruvananthapuram; 2018. p. 49.

26. Bhaskar J, Aravindakchan M, Balsalakumari PK, Rajeevan PK. Micropropagation studies in banana. South Indian Hort. 1993; 41:186-191. 